\title{
REGIONAL DISPARITIES IN THE EUROPEAN UNION FROM THE PERSPECTIVE OF ENVIRONMENTAL CONTEXT INDICATORS
}

\author{
Stefaniia Belinska*, Izabela Adamičková, Natália Turčeková, Miriam Buliková, Peter Bielik
}

Slovak University of Agriculture in Nitra, Nitra, Slovakia

\begin{abstract}
The agricultural sector is one of the most important sectors of the countries' economies and agricultural production has a huge socio-economic importance. In the current conditions of globalization and diversification of production, agriculture tries to achieve continuous development, realization of the potential, growth of the quantity and quality of the agricultural production, ensuring food security of the country. The quantitative and qualitative development of the agricultural sector takes place within a certain system, which is created under the influence of economic, social, and environmental factors based on innovations associated with transformation. These components of the current development of the agricultural sector are undergoing constant transformations, leading to the imbalances and the emergence of destructive processes within the complex system of the agricultural sector. Exploring regional disparities in terms of environmental and economic context indicators of CAP is strategically important for the stable rural and regional development of countries, increasing the competitiveness of agriculture, and sustainable and integrated development of regions. Based on the results of the calculations, we confirmed the effect of catching up between poorer and richer EU countries and identified the future trends in the occurrence and reduction of regional disparities.
\end{abstract}

Keywords: convergence; regional disparities; environmental context indicators of CAP; Gini coefficient; TAI index; Theil index

Regional differences relate to global structural transformation. It is necessary to study regional disparities in order to avoid an increase in disparities between economically strong and weak regions, to stop the inharmonious and unbalanced socio-economic development of regions, which, from the point of view of sustainable development, will disrupt the normal nature of economic processes in a country.

Disparities are understood as inequalities, differences, or heterogeneities. Differences between economic performance and the wellbeing of individual countries or regions are called regional disparities (Viturka, 2010).

Regional disparities represent a part of spatial disparities focused on the research of the most frequently investigated inequalities between predefined territorial units - regions. They are the results of the diverse initial conditions of the regions, their complex uneven development, the unbalanced use of their potentials, as well as the uneven impact of the market mechanism forces (Michalek, 2014).

By the term regional disparities, we mean the ability to adapt to economic and social transformations or the consequences of the differentiated state of factors that, to varying degrees, determine the development of the region (Korec, 2016).

Regional disparities are differences, inequalities of signs, phenomena or processes, the identification and comparison of which has a rational meaning (cognitive, economic, sociological, psychological, etc.) (Kutscherauer, 2010).

There are different definitions of regional disparities, but all researchers understand regional disparities as inequalities and differences between territorial or regional units.

It is necessary to study regional disparities in order to prevent an increase in disparities between economically strong and weak regions, to halt the inharmonious and unbalanced socio-economic development of the regions, which, in terms of sustainable development, disrupts normal economic processes in the country and impedes stable development.

For the analysis, measurement, monitoring and evaluation of regional disparities, we can use a set of indicators that will characterize various aspects of regional inequalities, namely, economic, social, territorial, and environmental.

A context indicator means data that provide simple and reliable information describing a variable related to the context, forming the basis for the development of other indicators. It provides information on the situation and its development in the country or region that are relevant to policy support.

Context indicators are defined and applied in such a way that they can be measurable and evaluated over time and/or space, allowing comparison and/or application of benchmarking based on the baseline value of the context indicator (Hincks, 2014).

The development of context indicators involves a methodological process of moving from abstract concepts to specific and more concrete measures to obtain political intelligence (Wong, 2003).

Context indicators take the form of quantifiable variables that are used to describe and measure the physical, demographic, social, economic, and environmental conditions in which a particular phenomenon occurs.

Context indicators characterize the social, economic, and environmental context of environment in which projects are implemented. They can be applied to a selected country, region, sector, or population group. These indicators form a coherent and consistent system. Context indicators explain complex interactions between social, economic, and environmental areas. In some cases, and countries, the focus may be on specific sectors or issues.

Rural areas need a comprehensive development policy that takes into account the specificities of each region; it shall be based on multiple economic sectors, not just agriculture, and support the development of production and provision of services, taking into account the bioeconomic features of a particular region.

The aim of the Common Agricultural Policy (CAP) and the Regional (cohesion) Policy is to achieve coherence, i.e. reduction of economic, social, and territorial disparities at the European Union level. The current regional policy embodies the social and agricultural components in their close synergies and interconnections and is a part of a broader structural policy (in terms of objectives, resource needs, funding, etc.). 
Therefore, there is an objective need to reveal the nature of regional disparities in the perspective of the CAP environmental context indicators because the territorial differentiation of factors determines the sectoral specialization and territorial organization of agricultural production, which affect the efficiency and productivity of agriculture in the country.

\section{Material and methods}

The size of regional disparities, including environmental indicators, and their reasons were determined using the Gini coefficient and the Theil index. These indices were used to assess convergence processes and their impact on regional disparities in the EU in 1995-2019 years. The presence of convergence processes indicates that lagging economies are gradually catching up with developed countries. The existence of convergence/divergence processes indicates whether regional disparities decreased or increased during the analysed period. The declining trend of inequality coefficients indicates the existence of convergence processes and a reduction in regional disparities.

The Gini coefficient measures income inequalities between people in regions and metropolitan areas. Regional disparities are measured using the unweighted Gini coefficient, which is calculated using the formula:

$$
G I N I=\frac{2}{N-1} \sum_{i=1}^{N-1}\left|F_{i}-Q_{i}\right|
$$

where:

$N \quad$ - the number of regions

$$
\begin{gathered}
F_{i}=\frac{i}{N} \\
Q_{i}=\frac{\sum_{j=1}^{i} y_{j}}{\sum_{i=1}^{n} y_{i}}
\end{gathered}
$$

$y_{i} \quad$ - the value of the variable y (e.g. GDP per capita, unemployment rate, etc.) in region $j$ when evaluated from the lowest $\left(y_{1}\right)$ to the highest $\left(y_{N}\right)$ among all regions within the country. The Gini coefficient is between 0 (perfect equality: $y$ is the same in all regions) to 1 (perfect inequality: $y$ is zero in all regions except one)

The Theil entropy index measures regional disparities between all regions (GDP, labour productivity, income, etc.). Theil index measures total spatial differences. The Theil index can be considered as an indicator that measures the significant superiority of one region over another, the lack of diversification, the presence of relative isolation, economic and social inequality, etc.

Theil entropic index is calculated according to the formula:

$$
\text { Theil }=\frac{1}{N} \sum_{i=1}^{N} \frac{y_{i}}{\bar{y}} \cdot \ln \left(\frac{y_{i}}{\bar{y}}\right)
$$

where:

$N$ - the number of regions/countries

$y_{i} \quad$ - a variable in the $i$-th region (i.e. GDP per capita, household income, life expectancy, etc.)

$\bar{y} \quad-$ is the average value of the variable over all regions

The Theil index ranges from zero to $\infty$, with zero representing the same distribution, higher values representing a higher level of inequality, and the value of representing perfect inequality. The lower index value means lower degree of inequality between regions and vice versa.

Using the Total Agricultural Index, we can quantify the country's agriculture from the economic point of view. The aggregate Total agricultural index or agriculture importance index (TAl) is formulated as a "deficiency rate", or as a "surfeit rate" of countries in each of the three areas - agriculture value added (\% of GDP) $(x 1)$, share of employment in agriculture in total employment $(x 2)$, value added per agricultural worker (x3) (Sojková and Stehlíková, 2004). In terms of surfeit or deficit, we can analyse the distance that the country still must cover to reach the recommended direction or target. Thus, $I_{i j}$ is defined as the surfeit rate for the $j$-country with respect to the variable $x_{i}$ as:

$$
I_{i j}=\frac{\max _{k}\left\{x_{i k}\right\}-x_{i k}}{\max _{k}\left\{x_{i k}\right\}-\min _{k}\left\{x_{i k}\right\}}
$$

where:

$i=1,2,3-$ index of indicators

$j=1,2 \ldots n-$ index of the country

Each indicator of surfeit, resp. deficiency for $j$-country $l_{i j} i=1,2,3$ is recalculated to be in the range from 0 to 1 .

The average index $I_{j}$ for the $j$-country of the three indicators is defined as a simple non-weighted average of this three sub-indices $l_{i j}$ :

$$
T A I=I_{j}=\frac{1}{3} \sum_{i=1}^{3} I_{i j}
$$

where:

$11 \quad$ - index of the share of value added in agriculture in total GDP

12 - index of the share of employment in agriculture in total employment

B - index of labour productivity in agriculture

The surfeit in the Total Agricultural Index of the countryj can be interpreted as an excessive position of agriculture in a given country, related to lower productivity of this sector. This means that the TAl value approaching 1 indicates the best economic situation of agriculture in the country and, conversely, the closer the index is to zero, the worse situation in the agriculture sector.

In this paper, we wanted to point out the current level of regional disparities between the EU-28 countries by examining selected environmental and economic context indicators of the CAP. We monitored the development of these indicators in order to compare the size of disparities in the analysed period of 1995-2018 years. In the last part, we devoted a comparative analysis of countries based on macroeconomic indicators and the calculated Total agriculture index. Data were taken from Eurostat database and Agri-food data portal for the period 1995-2019 years.

\section{Results and discussion}

The importance of the agricultural sector and the competitiveness of its production in the domestic and foreign markets is increasing. Effective agricultural production is the basis for ensuring the food security of the state, satisfying the needs of the population with high-quality food in sufficient quantities and assortment. Agriculture and its agri-food sector play an important role in the life of the EU as an association for regional integration and contribute to the preservation and strengthening of European values. Global development can help in reducing agricultural inequalities between countries through integration processes based on technological progress. 
The regional policy of the EU contributes to the achievement of objectives, as countries and regions differ significantly in specific economic conditions and funding levels. The current situation on world markets and progress in the WTO agreements on the liberalization of trade in agricultural products on the one hand, and disparities in the level of development of the agricultural sector in individual EU countries (historical level of direct payments, labour productivity, farm structure) on the other, require a regular review of the CAP, improving policy instruments and setting new goals.

In the 2014-2020 programming period, contextual indicators are used for the purpose of comprehensive monitoring, evaluation and performance assessment of the CAP. Context indicators provide general information about the CAP. The context indicators of the CAP reflect trends in socio-economic, sectoral (agricultural) and environmental phenomena and become relevant and topical for policy. The aim of context indicators is to measure the impact of policies on society.

Context indicators provide quantified information and can identify gaps and needs over time. They characterize the social and economic environment in which the political program will be implemented and attract financial funds from the structural funds. They can be applied to a selected country, region or sector and explain the complex interactions between them.

A set of context indicators provides information on the situations and trends in agriculture and rural areas. Context indicators should consider the characteristics of the rural areas that we want to improve. Therefore, important impact indicators are often included in the list of context indicators. The environmental indicators taken into account in the methodological procedure should contain information related to land cover, water abstraction in agriculture, water quality, soil organic matter in arable land, soil erosion by water, production of renewable energy from agriculture and forestry, energy use in agriculture, forestry and food industry, and emissions from agriculture.

One of the principles of context indicators is that data should be available from EU sources, at least at the national level. The use of a common Eurostat definition for the calculation and control of the EU statistical data sources is required to ensure the availability of data on common context indicators.

There are economic, social and environmental dimensions such as the impact of climate change on agriculture and impact of agriculture sector on climate change and air quality; pollution and water scarcity, soil erosion, increasing pressure on natural resources and unequal distribution of resources.

By 2021, the main problems of the CAP in the field of agriculture in the EU countries have been identified:

$\square$ intensive export subsidies;

$\square$ irrational and unfair distribution of subsidies between agricultural holdings;

$\square$ increasing public opposition to CAP priorities;

$\square$ protectionist prices for agricultural production, which significantly reduced the competitiveness of agricultural products of other market participants;

$\square$ the allocation of significant amounts of funds to cover the needs of the CAP;

$\square$ the complexity of resolving environmental issues due to a tough costbenefit approach to assessing the effectiveness of the EU CAP budgets;

$\square$ insufficient financing of rural development.

The EU CAP had to take into account the regional factor due to two circumstances: firstly, the expansion of the eastern borders of the EU and, secondly, the priority of rural development policy and, therefore, the redistribution of financial support to the agricultural sector in favour of socially oriented and environmental measures.

The priority of the EU CAP is food security, and the development of organic farming. Organic production is more sustainable than traditional one, less harmful to the environment, able to adapt to climate change and maintain a stable level of fertility in the long term.

$\square$ The essence of organic farming standards is reflected in the following principles:

$\square$ The principle of ecology (organic farming should be based on the principles of existence of natural ecological systems and cycles, work with them and support them).

$\square$ The principle of health (organic farming should support and improve the health of soil, plants, animals, humans and the planet as an indivisible whole).

$\square$ The principle of care (management of organic farming should be preventive and responsible for the protection of the health and wellbeing of present and future generations and the environment).

$\square$ The principle of fairness (organic farming must be built on relationships that guarantee fairness, considering the shared environment and life opportunities).

The EU recognizes food security and the development of organic farming as priorities of the CAP strategy. It maintains the efficiency of agricultural production and food security of the CAP through subsidy mechanisms and the stabilization of food prices at a minimum level. Assessing the agricultural characteristics of the EU countries, we have identified certain development trends: diversification and strengthening of the multifunctionality of industry, state policy to support agricultural holdings and farmers, and development of rural areas.

Structural regional disparities in the economic development of countries negatively affect socio-economic development and require the implementation of appropriate measures to compensate for these disparities. Therefore, it is very important to study this inequality in order to determine the strengths and weaknesses of the regions, their growth potential and threats, in order to take them into account when formulating a strategy for economic development of agriculture.

Compared to large regions of the EU, we still observe large regional differences in GDP per capita, only changing their structure and character. Since the beginning of 2002, regional disparities in GDP per capita have clearly decreased. In low-income countries, regional disparities increased between 2000 and 2007, and became more important than regional disparities between countries. Since 2011, this trend has reversed and inequality within countries has decreased significantly. In 2015-2018, regional disparities between countries have decreased again, while disparities within countries have increased. Regional cohesion policies and economic governance mechanisms will help in reducing inequality and increasing inclusiveness.

In 2018, the largest regional disparities, where GDP per capita was higher than labour productivity, were observed in Luxembourg (263\% of the EU average compared to $165 \%$ ), Prague (192\% compared to $121 \%$ ) and Budapest (145\% compared to 75\%). By contrast, the largest differences between regions where labour productivity was higher than GDP per capita were in the French regions: Guyana (105\% of the EU average compared to $48 \%$ ), Mayotte (79\% compared to 30\%) and Guadeloupe (107\% in compared to $73 \%$ ); then in Sicily in Italy (90\% compared to 59\%) and Hainaut in Belgium (105\% compared to $75 \%$ ). Regional differences in labour productivity are significantly smaller than in GDP per capita. 


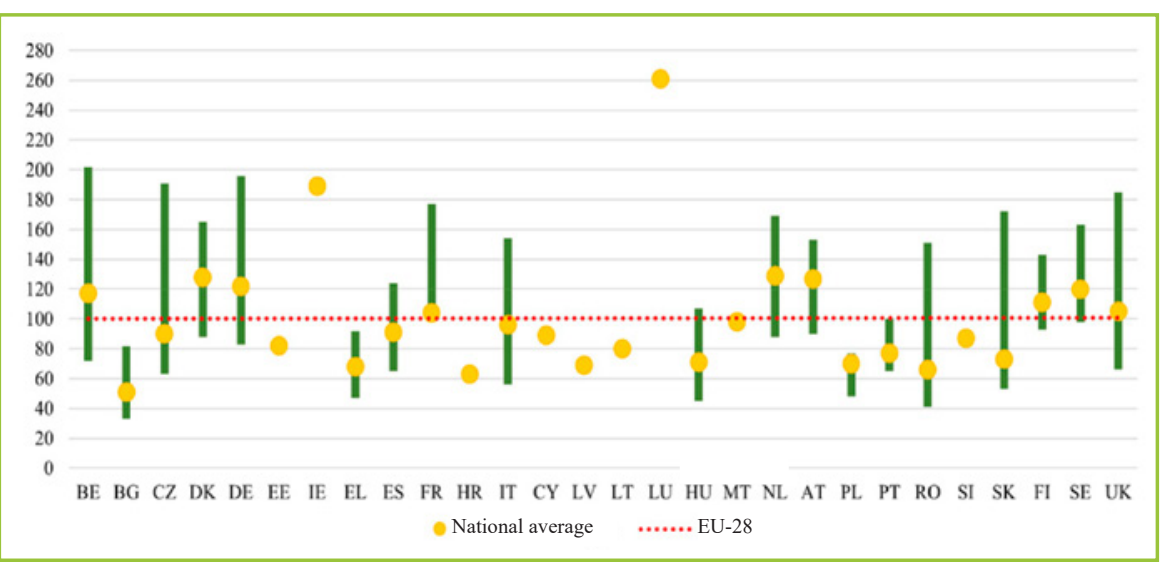

Figure 1 Regional GDP per capita in PPS, EU-28 = 100\%, 2018 Source: Authors' own processing based on data from Eurostat

EU - European Union, BE - Belgium, BG - Bulgaria, CZ - Czechia, DK - Denmark, DE - Germany, EE - Estonia, IE Ireland, EL - Greece, ES - Spain, FR - France, HR - Croatia, IT - Italy, CY - Cyprus, LV - Latvia, LT - Lithuania, LU Luxembourg, HU - Hungary, MT - Malta, NL - Netherlands, AT - Austria, PL - Poland, PT - Portugal, RO - Romania, SI - Slovenia, SK - Slovakia, FI - Finland, SE - Sweden, UK - United Kingdom
The Nordic countries have remarkably high levels of GDP per capita, i.e. Great Britain, Ireland, the Scandinavian countries (Norway, Sweden, Finland, and Denmark); Germany, France, Netherlands, Belgium, Luxembourg, Austria, and northern Italy (Figure 1). Most regions of Spain, Portugal, southern Italy, and Greece have low levels of GDP per capita. In Poland and the Czech Republic, as well as in other countries, there are more significant regional disparities in GDP per capita. The lowest values of GDP per capita are in Latvia, Greece, Croatia, Romania, and Bulgaria. Over the last ten years, economically strong countries have shown good indicators of GDP per capita growth. These include Sweden, Finland, the Netherlands, Belgium, Germany, Austria, and Ireland. Germany maintained good economic performance, while Denmark and Italy achieved the worst results.

Figure 2 shows the dynamics of the Gini coefficient (left scale) and the Theil index (right scale), which point out a significant reduction in the difference between countries in terms of GDP per capita in the period 1995-2007. We can see that during the financial crisis in 1997-1998 and the crisis of the stock markets in 2008, the gap between countries widened significantly. Developments are rather mixed, the fluctuations in the coefficients observed before 2008 probably reflect a certain influence of the economic cycle on the level of disparities, different socio-economic resistance of countries to crises. Convergence is mixed in the $\mathrm{EU}$ countries, i.e. the initial differences in 2000 turned into an inconsistent strong convergence that lasted

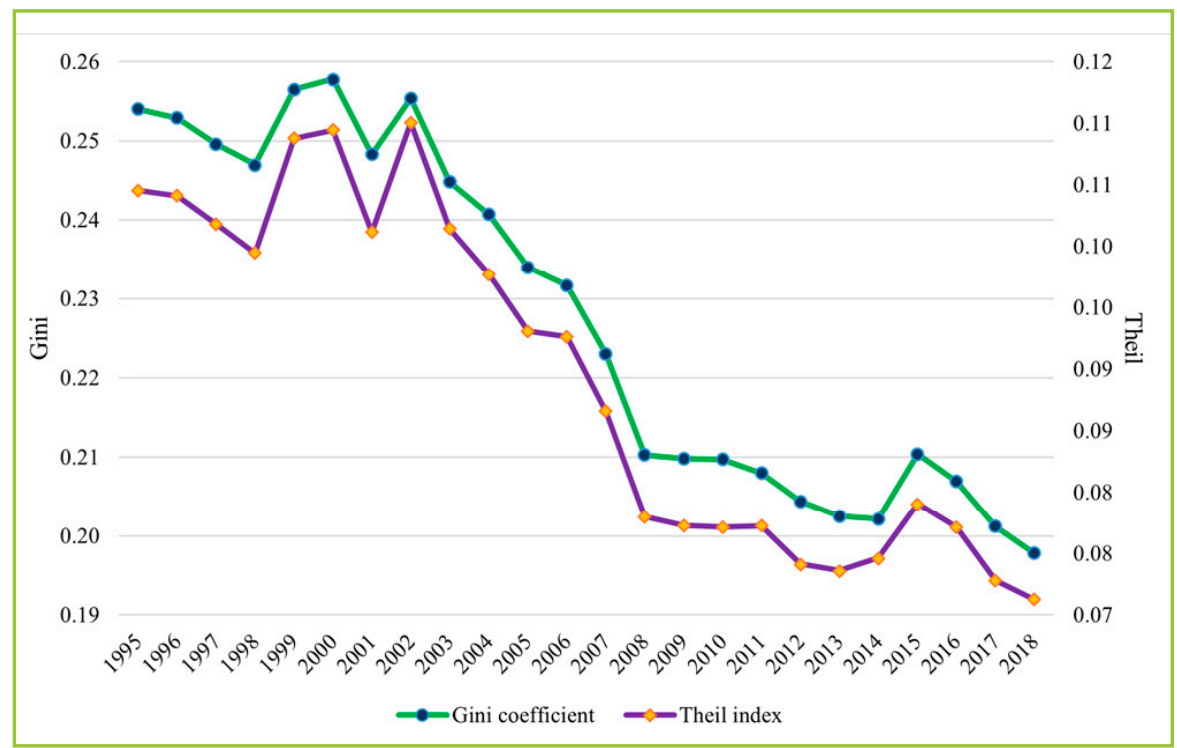

Figure 2 Regional disparities between EU countries in the years 1995-2018 Source: Authors' own calculations based on data from Eurostat until 2008, when the Gini coefficient declined, and they turned to inequalities again.

In 2014-2015, disparities between countries also increased, partly due to the implementation of the next phase of the $\mathrm{EU}$ agricultural policy reform. The Gini coefficient and the Theil index clearly show that differences between countries are narrowing. This means that disparities in the EU are decreasing, mainly due to convergence of countries. Thus, we can say that the convergence processes gradually replaced by diversification processes, since the countries began to develop according to their own development trajectory and found their place in the EU's economic system. Therefore, the objectives of the CAP and EU regional policy to reduce regional disparities have been achieved to some extent.

We confirmed the mixed convergence between the EU countries based on GDP per capita. The dynamics of inequality indices for GDP per capita in the period 1995-2018 indicates a gradual process of diminishing differences between the levels of development of the countries. The main fluctuations in the Gini coefficient and Theil index occur during the crisis and the post-crisis period. In view of this, we recommend paying more attention to anti-crisis measures, especially in less developed countries, in order to get out of the crisis more quickly and achieve the post-crisis level of development, while reducing the burden on EU fiscal and monetary policies. Otherwise, the financial burden on fiscal and monetary policies of the EU countries will increase, so that countries will reach the level of pre-crisis development.

According to the Table 1 in the regional context, we can state that the most developed EU countries (first in the ranking according to GDP per capita) are the top ten: Luxembourg, Ireland, the Netherlands, Denmark, Austria, Germany, Sweden, Belgium, Finland, France; they have a relatively low share of agriculture gross value added in total GDP, while the TAl index has relatively high values.

The correlation coefficient between the GDP per capita rating and the TAl index rating is positive, but low (0.4745), and between the GDP per capita and the share of value added in agriculture in total GDP - negative and highly significant $(-0.8560)$.

Thus, it can be assumed that the most developed EU countries are gradually reducing the share of value added in agriculture, mainly by improving the quality of its development (especially increasing labour productivity). This is evidenced by the focus of EU agricultural policy on the continuation of structural reforms, initiation and support of changes in the economies of the 
Table 1 Comparison of EU countries based on economic context indicators of agriculture and TAl index

\begin{tabular}{|c|c|c|c|c|c|c|}
\hline Country & GDP per capita (million EUR) 2018 & Rank & GVA AGRI (\% of GDP) 2019 & Rank & TAI, 2019 & Rank \\
\hline Luxembourg & 80870 & 1 & 0.2 & 28 & 0.82 & 2 \\
\hline Ireland & 58650 & 2 & 0.9 & 23 & 0.74 & 6 \\
\hline Netherlands & 39920 & 3 & 1.7 & 18 & 0.54 & 23 \\
\hline Denmark & 39670 & 4 & 1.4 & 20 & 0.57 & 18 \\
\hline Austria & 39450 & 5 & 1.1 & 22 & 0.75 & 5 \\
\hline Germany & 37760 & 6 & 0.8 & 24 & 0.73 & 7 \\
\hline Sweden & 37310 & 7 & 1.4 & 21 & 0.55 & 21 \\
\hline Belgium & 36230 & 8 & 0.4 & 27 & 0.82 & 1 \\
\hline Finland & 34230 & 9 & 2.2 & 12 & 0.50 & 25 \\
\hline United Kingdom & 32570 & 10 & 0.6 & 26 & 0.78 & 4 \\
\hline France & 32070 & 11 & 1.6 & 19 & 0.61 & 16 \\
\hline Malta & 30260 & 12 & 0.8 & 25 & 0.81 & 3 \\
\hline Italy & 29670 & 13 & 1.9 & 17 & 0.64 & 13 \\
\hline Spain & 28110 & 14 & 2.7 & 9 & 0.54 & 22 \\
\hline Czechia & 28020 & 15 & 1.9 & 16 & 0.71 & 8 \\
\hline Cyprus & 27640 & 16 & 2 & 14 & 0.67 & 12 \\
\hline Slovenia & 26900 & 17 & 2 & 15 & 0.70 & 9 \\
\hline Estonia & 25270 & 18 & 2.9 & 7 & 0.55 & 19 \\
\hline Lithuania & 24850 & 19 & 3 & 6 & 0.61 & 17 \\
\hline Portugal & 23810 & 20 & 2.1 & 13 & 0.68 & 10 \\
\hline Slovakia & 22590 & 21 & 2.5 & 10 & 0.62 & 15 \\
\hline Hungary & 21900 & 22 & 3.5 & 4 & 0.55 & 20 \\
\hline Poland & 21820 & 23 & 2.2 & 11 & 0.67 & 11 \\
\hline Latvia & 21260 & 24 & 3.7 & 3 & 0.53 & 24 \\
\hline Greece & 21050 & 25 & 3.7 & 2 & 0.48 & 27 \\
\hline Romania & 20320 & 26 & 4.1 & 1 & 0.33 & 28 \\
\hline Croatia & 19490 & 27 & 2.8 & 8 & 0.64 & 14 \\
\hline Bulgaria & 15720 & 28 & 3.2 & 5 & 0.49 & 26 \\
\hline
\end{tabular}

EU's most developed countries towards the development of high-tech sectors, such as artificial intelligence and information technology, which are among the most profitable and do not require large financial subsidies to support the development of agriculture in the EU, which puts a strain on the budgets of countries.

A comparative analysis of the distribution of countries by the share of the agricultural sector in GDP and the values of the calculated TAI index show that the EU-28 countries are clearly divided into agricultural countries that serve as bases for agricultural production (usually less developed countries) and countries that are oriented towards the development of more technological sectors of the economy and are heading towards the industrial revolution Industry 4.0. This situation is to some extent due to natural factors and the historical orientation of economic systems for food production.

\section{Conclusions}

The main factors influencing the CAP and requiring new governance mechanisms are: the need to ensure food security; the multiplier effect of the agricultural sector; the specifics of agricultural production associated with significant risks; the appropriateness of regulating cross-sectoral relations to ensure the profitability and stability of agricultural production; maintaining economic competition; solution of social issues.

The economic development of agriculture as a multifunctional and multipurpose system to a large extent depends on the economic development of each region of the country, which performs certain functions and has economic resources.

Based on the analysis of regional GDP per capita, we found that in lowincome countries, regional disparities increased between 2000 and 2007, and became more important than regional differences between countries. Since 2014, differences between EU countries have been decreasing, but within the country, disparities between regions have increased.

The dynamics of the Gini coefficient and the Theil index showed a significant reduction in the difference between countries in terms of GDP per capita (in PPS) in the period 1995-2007. In the years 2008-2011 during the global financial crisis and in the years 2014-2015 during the new phase of implementation of CAP reforms, disparities have increased significantly. In general, the declining dynamics of these indicators of inequality confirms the positive dynamics of convergence processes and the relative success of the 
CAP, which is aimed at reducing the imbalances between countries within the common economic space of the EU. The implementation of the CAP initially led to convergence processes, and as the level of development of the countries that joined the EU increased, the diversification processes of the production of specific agricultural products gradually began, which allowed them to occupy their own position in the structure of the EU agricultural sector.

The result of the comparison of the calculated TAI index values shows that the EU-28 countries are quite clearly divided into agricultural countries and countries leading to the industrial revolution Industry 4.0.

Based on the analysis of convergent-divergent relationships and regional disparities between EU countries, we conclude that there is a catchup effect between less developed regions. This means that highly developed regions are lagging behind in terms of the economic side of agriculture, while underdeveloped regions are improving their situation, which leads to a longterm convergence of levels of regional development in the EU countries and reduction in regional disparities.

\section{Acknowledgement}

This publication was supported by the Operational programme Integrated Infrastructure within the project: Demand-driven research for the sustainable and innovative food, Drive4SIFood 313011V336, co-financed by the European Regional Development Fund.

\section{References}

BALÁŽOVÁ, E. a i. 2017. Politika súdržnosti - príležitosti a ohrozenia. Nitra : SPU, 2017, 106 s. ISBN 978-80-552-1778-9. http://www.slpk.sk/eldo/2018/ dl/9788055217789/9788055217789.pdf

BARRO, R. J. - SALA-I-MARTIN, X. 1992. Convergence. In Journal of Political Economy, vol. 100, 1992, no. 2, pp. 233-251. ISSN 0022-3808. https://dash.harvard.edu/ handle/1/3451299

BUČEK, M. - GERULOVÁ, L. - KOVÁČ, U. 2008. Metódy hodnotenia regionálnej konvergencie. In Region direct: international scientific journal, roč. 1, 2008, č. 2, s. 75-89. ISSN 1337-8473. https://www.ceeol.com/search/article-detail?id=293244

BUČEK, M. 1999. Regional disparities in transition in the Slovak Republic. In European Urban and Regional Studies, vol. 6, 1999, no. 4, pp. 360-364. ISSN 364-370. http:// journals.sagepub.com/doi/pdf/10.1177/096977649900600411

BUCHER, S. 2016. Konkurencieschopnost'a regionálne disparity v európe: Vybrané ekologické, sociálne a ekonomické indikátory. Košice : Univerzita Pavla Jozefa Šafárika, 2016, 98 s. ISBN 978-80-8152-447-9. https://www.researchgate.net/publication/315648197 KONKURENCIESCHOPNOST A REGIONALNE DISPARITY V EUROPE VYBRANE EKOLOGICKE SOCIALNE A EKONOMICKE INDIKATORY

ĎURIŠOVÁ, E. - TURČEKOVÁ, N. - URBÁNOVÁ, M. - ČERYOVÁ, D. - SVETLANSKÁ, T. 2018. Competitive export performance in EU countries in agri - food sector. In International scientific days 2018, Praha : Wolters Kluwer ČR, 2018, pp. 62-72. ISBN 978-80-7598180-6. https://doi.org/10.15414/isd2018.s1.04

EUROPEAN COMMISSION. 2017. Technical handbook on the monitoring and evaluation framework of the common agricultural policy 2014-2020. Brussels : Directorategeneral for agriculture and rural development, 2017, 85 p. https://ec.europa.eu/ info/sites/info/files/food-farming-fisheries/key policies/documents/technicalhandbook-monitoring-evaluation-framework june17 en.pdf

EUROPEAN COMMISSION. Agri-Food data portal. https://agridata.ec.europa.eu/ extensions/DataPortal/home.html

EUROPEAN COMMISSION. Common agricultural policy. https://ec.europa.eu/info/foodfarming-fisheries/key-policies/common-agricultural-policy en

EURÓPSKA ÚNIA. 2015. Monitorovací a hodnotiaci rámec Spoločnej polnohospodárskej politiky 2014 - 2020. Luxemburg : Úrad pre vydávanie publikácií Európskej únie, 2015, 20 s. ISBN 978-92-79-48196-3. http://publications.europa.eu/resource/ genpub/PUB KF0415328SKN.1.1

GOECKE, H. - HÜTHER, M. 2016. Regional Convergence in Europe. In Intereconomics, vol. 51, 2016, no. 3, pp. 165-171. ISSN 1613-964X. http://hdl.handle.net/10419/146066

HINCKS, S. 2014. Contextual Indicators. In Michalos, A.C. (Ed.). Encyclopedia of Quality of Life and Well-Being Research. Dordrecht : Springer Nature, 2014, pp. 1268-1270. https://www.research.manchester.ac.uk/portal/en/publications/contextualindicators(9bcc5ee4-c68b-481c-aa3c-d15a6aa94c4a).html

IAMMARINO, S. - RODRIGUEZ-POSE, A. - STORPERY, M. 2019. Regional inequality in Europe: evidence, theory and policy implications. In Journal of Economic Geography, vol. 19, 2019, no. 2, pp. 273-298. https://academic.oup.com/joeg/article/19/2/273/4989323

KOREC, P. - ONDOŠ, S. - RUSNÁK, J. 2016. Regionálne disparity na Slovensku; Niekolko poznámok k ich bádaniu. In Acta Geographica Universitatis Comenianae, roč. 60, 2016, no. 2, pp. 257-293. http://www.humannageografia.sk/clanky/60 207 Korec et al.pdf

KUTSCHERAUER, A. et al. 2010. Regional disparities: Disparities in country regional development - concept, theory, identification and assessment. Ostrava : VŠB, 2010, 152 p. http://disparity.vsb.cz/edice cd/cd11 regdis mono angl/pdf/Regional\%20 disparities.pdf

MATLOVIČ, R. - MATLOVIČOVÁ, K. 2011. Regionálne disparity a ich riešenie na Slovensku v rozličných kontextoch. In Folia Geographica, roč. LIII, 2011, č. 18, s. 8-87. ISSN 13366157. https://www.unipo.sk/public/media/26612/REGIONALNE DISPARITY A ICH RIESENIE NA SLOVENSKU V ROZLICNYCH KONTEXTOCH-MatlovicMatlovicova-2011 opt.pdf

MICHÁLEK, A. 2014. Teoretické východiská a metodické postupy výskumu priestorových a regionálnych disparít. In Geographia Slovaca, roč. 28, 2014, s. 7-21. https://www. sav.sk/journals/uploads/02051156Geog\%20Slovaca 28.pdf

MIKUŠ, 0. - KUKOČ, M. - JEŽ ROGELJ, M. 2019. The coherence of common policies of the $\mathrm{EU}$ in territorial cohesion: A never-ending discourse? A review. In Agricultural Economics, vol. 65, 2019, no. 3, pp. 143-149. https://www.agriculturejournals.cz/ web/agricecon.htm?type $=$ article\&id=229 2018-AGRICECON

OECD. 2016. OECD Regions at a Glance 2016. Paris : OECD Publishing, 2016, 184 p. ISBN 978-92-64-25679-8. https://doi.org/10.1787/reg glance-2016-en

OECD. 2019. OECD Regional Outlook 2019: Leveraging Megatrends for Cities and Rural Areas. Paris : OECD Publishing, 2019, 240 p. ISBN 978-92-64-31283-8. https://doi. org/10.1787/9789264312838-en

REGULATION (EU) No 1306/2013 of the European Parliament and of the Council of 17 December 2013 on the financing, management and monitoring of the common agricultural policy and repealing Council Regulations (EEC) No 352/78, (EC) No 165/94, (EC) No 2799/98, (EC) No 814/2000, (EC) No 1290/2005 and (EC) No 485/2008. https://eur-lex.europa.eu/legal-content/en/ALL/?uri=CELEX:32013R1306

REGULATION (EU) No 1307/2013 of the European Parliament and of the Council of 17 December 2013 establishing rules for direct payments to farmers under support schemes within the framework of the common agricultural policy and repealing Council Regulation (EC) No 637/2008 and Council Regulation (EC) No 73/2009. https://eur-lex.europa.eu/legal-content/en/ALL/?uri=CELEX:32013R1307

SOJKOVÁ, Z. - STEHLÍKOVÁ, B. 2004. Comparative analysis of the economic role of agriculture in the EU countries. In Agric. Econ, vol. 50, 2004, no. 8. pp. 369-375. ISSN 1805-9295. https://www.agriculturejournals.cz/publicFiles/58767.pdf

TÓTH, M. 2019. Vplyv integrácie a globalizácie na štruktúru a podnikatel'ské riziko v polnohospodárstve na Slovensku: vedecká monografia. Nitra : SPU, 2019, $107 \mathrm{~s}$. ISBN 978-80-552-2105-2. https://doi.org/10.15414/2019.9788055221052

TVRDOŇ, M. 2012. Cohesion Policy, Convergence and Regional Disparities: The Case of the European Union. In WSEAS Transactions on Business and Economics, vol. 9, 2012, no. 2, pp. 89-99. ISSN 2224-2899. https://www.researchgate. net/publication/268004395 Cohesion Policy Convergence and Regional Disparities the Case of the European Union

VILLAVERDE, J. - MAZA, A. 2009. Measurement of regional economic disparities. Brugge : UNU-CRISWorking papers, W-2009/12, 2009, 45 p. http://cris.unu.edu/sites/cris.unu. edu/files/W-2009-12.pdf

VITURKA, M. 2010. Regionální disparity a jejich hodnocení v kontextu regionální politiky. In Geografie - sborník České geografické společnosti, roč. 115, 2010, č. 2, s. 131143. ISSN 1212-0014. http://geography.cz/sbornik/wp-content/uploads/2009/03/ gcgs022010 viturka.pdf

WONG, C. 2003. Indicators at the Crossroads: Ideas, Methods and Applications. In The Town Planning Review, vol. 74, 2003, no. 3, pp. 253-279. https://www.jstor.org/ $\underline{\text { stable/40112561 }}$

\section{Contact address}

Stefaniia Belinska, Slovak University of Agriculture in Nitra, Faculty of Economics and Management, Department of Economics, Tr. Andreja Hlinku 2,94976 Nitra, 푱 +42137641 45 85, e-mail: xbelinskas@uniag.sk 